\title{
Is it time for a Global Mining Initiative 2.0?
}

\author{
Michael Tost ${ }^{1 *}$, Vighnesh Chandurkar ${ }^{2}$, Michael Hitch $^{2}$, Peter Moser ${ }^{1}$ and Susanne Feiel ${ }^{1}$ \\ ${ }^{1}$ Chair of Mining Engineering and Mineral Economics, Montanuniversitaet Leoben, Austria \\ 2 The Australian Centre for Sustainable Mining Practices, School of Mining Engineering, UNSW, Australia
}

\begin{abstract}
From 1998-2002 the world's leading mining and metals companies developed the Global Mining Initiative (GMI) to understand their industry's role in the transition to sustainable development and to ensure its long-term contribution to sustainable development (SD). Since then, the industry has come a long way: For example, operational safety and health have improved significantly, environmental management systems and impact assessments have become the norm, community relations have been established, many mining companies report annually on their contributions to SD and the International Council on Mining and Metals (ICMM) has taken on the recommendations of the GMI as an industry association.

However, since the GMI the concept of sustainable development has been evolving from a rather generic and loose definition ("weak sustainability"), to an absolute and strict definition of sustainability, based on the boundaries of our planet ("strong sustainability"). Similarly, other concepts such as corporate social responsibility (CSR) have evolved and even deviated from their initial intentions.

This paper presents results from a literature review looking at how far this transition has moved from a scientific debate towards becoming mainstream. Furthermore, it explores, by using qualitative comparison analysis, if the current efforts of the large mining companies are still sufficient or if the industry is again at risk of falling behind societal expectations and hence should once again come together - for a GMI 2.0 - in order to update its approach.

We conclude that the mining industry, whilst in a "weak sustainability" position and behind the peer group on climate change and natural capital considerations, is aligned with current societal expectations, expressed through the Sustainable Development Goals, and therefore there is no need for a GMI 2.0 at present.
\end{abstract}

Keywords: sustainable development, sustainability, planetary boundaries, Global Mining Initiative, mining, natural capital

\section{Introduction}

Based on increasing environmental pressures, the concept of $\mathrm{SD}$ is evolving from a rather generic and loose definition ("weak sustainability"), based on the Brundlandt Report, to a strict definition of sustainability, based on the boundaries of our planet ("strong sustainability") (Turner 1993).

From 1998-2002 the world's leading mining and metals companies developed the Global Mining Initiative (GMI) to understand their industry's role in and to ensure its longterm contribution to sustainable development.

This paper presents results from a literature review, looking at how far this transition from a "weak" to a "strong" definition has moved from a scientific debate towards becoming societal mainstream. Given that the GMI ended 15 years ago, it explores, by literature based qualitative comparison analysis, if the current efforts of the mining industry are in line with societal expectations or if the industry is again at risk of falling behind and hence should once again come together for a GMI 2.0.

\subsection{History of SD and sustainability}

Whilst aspects and mentions of sustainability can be traced back much further, it was environmental problems, as a result of the "great acceleration" of economic growth after World War II, which brought the issue of sustainability to the attention of the public. The Club of Rome published "The Limits to Growth", which states that

"the earth's interlocking resources - the global system of nature in which we all live - probably cannot support present rates of economic and population growth much beyond the year 2100, if that long, even with advanced technology" (Donella 1972)

The United Nations (UN) played a key role in developing the agenda. In 1987, the UN's World Commission on Environment and Development came up with a definition of sustainable development that today is still the one most often referred to:

"Sustainable development is development that meets the needs of the present without compromising the ability of future generations to meet their own needs." (WCED 1987, paragraph 1)

What is interesting though is that the next sentences, which link sustainable development to sustainability, are hardly ever considered in these references:

"It contains within it two key concepts:

- the concept of 'needs', in particular the essential needs of the world's poor, to which overriding priority should be given; and

- the idea of limitations imposed by the state of technology and social organization on the environment's ability to meet present and future needs.

* Corresponding Author: M. Tost, michael.tost@ unileoben.ac.at, phone: +43 6644529872

Copyright @ 2017 Canamaple Academia Services, http://press.camdemia.ca

DOI: $10.15273 /$ gree.2017.02.008 
Thus, the goals of economic and social development must be defined in terms of sustainability in all countries - developed or developing, market-oriented or centrally planned. Interpretations will vary, but must share certain general features and must flow from a consensus on the basic concept of sustainable development and on a broad strategic framework for achieving it." (ibid., paragraphs 1,2)

Although it doesn't give a clear definition of sustainability ("interpretations will vary") there is a link between development and ecological limits.

Five years later, one of the outputs of the UN's Conference on Environment and Development in Rio de Janeiro, the so-called Rio declaration put a stronger emphasis on human development relative to environmental protection. Principle 1 and principle 4 of the declaration state:

"Human beings are at the centre of concerns for sustainable development. They are entitled to a healthy and productive life in harmony with nature.

In order to achieve sustainable development, environmental protection shall constitute an integral part of the development process and cannot be considered in isolation from it." (UNCED 1992, p. 1-2)

The Rio declaration was key for SD to be modelled using three pillars on equal footing as shown in Figure 1.

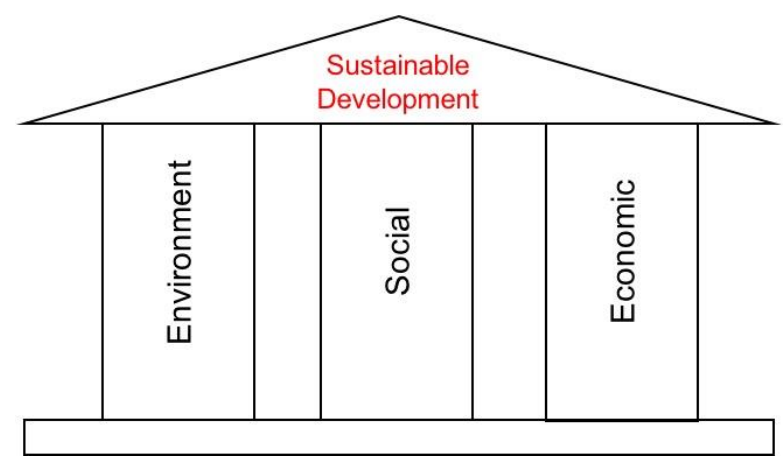

Figure 1: Three pillars of sustainable development.

Further UN conferences with relevance were the Millennium Summit in New York in 2000 and the Conference on SD, or Rio +20, in 2012. At the former, the Millennium Development Goals (MDGs), a set of eight goals were agreed upon. At the later, the key result was the non-binding document "The future we want" in which it was agreed to develop the Sustainable Development Goals (SDGs, see below) to succeed the MDGs.

Another, related, concept is corporate social responsibility (CSR). CSR grew in importance at the time of the "great acceleration", particularly in the USA (Carroll 2008). The book "Social Responsibilities of the Businessman" gave a still considered to be important definition of CSR, or social responsibility (SR) as it was called back then:

"It (SR) refers to the obligations of businessmen to pursue those policies, to make those decisions, or to follow those lines of action which are desirable in terms of the objectives and values of our society." (Bowen 1954)

In his paper "A History of Corporate Social Responsibility: Concepts and Practices", Carroll links CSR to sustainability:

"Sustainability was another important complementary theme that attracted significant interest in the 1990s. Though initially defined in terms of the natural environment, it evolved into a more encompassing concept that embraced the larger social and stakeholder environment." (Carroll 2008)

\subsection{Mining's journey}

Mining has for centuries, even millennia, been a source of great economic wealth but also social and environmental concern in the context of sustainability. This paper focuses only on these consequences of mining and is not looking into aspects of the finite nature of nonrenewable resources.

The "great acceleration" meant that demand for mineral resources was growing exponentially (Moser 2016). This increase in production meant that mines became more and larger and so did the environmental and social consequences - leading to ever more conflicts (e.g. Ok Tedi in 1984 and Bougainville Copper in 1989) and putting ever more pressure on the industry to improve its social and environmental performance.

In 1998, the CEOs of the largest mining companies decided that a change in the way industry approached these problems was needed. Through the World Business Council for Sustainable Development (WBCSD) they launched an initiative called the Global Mining Initiative. The WBCSD then asked the International Institute for Environment and Development (IIED) to conduct a global study to define the meaning of sustainable development for mining - the Mining, Minerals and Sustainable Development project (MMSD). As a key result of the MMSD, the report "Breaking New Ground" was issued, describing what sustainable development should mean for the industry:

"One of the greatest challenges facing the world today is integrating economic activity with environmental integrity, social concerns, and effective governance systems. The goal of that integration can be seen as 'sustainable development'. In the context of the minerals sector, the goal should be to maximize the contribution to the well-being of the current generation in a way that ensures an equitable distribution of its costs and benefits, without reducing the potential for future generations to meet their own needs." (IIED 2002)

The GMI and MMSD also resulted in the creation of the industry body ICMM (International Council on Mining and Metals) in 2001. A year later, at the final conference of the MMSD, the participating mining CEOs signed a list of commitments, called the Toronto Declaration, and the ICMM was mandated with taking them forward. It developed 10 principles and eight position statements for its members and the mining industry to follow (ICMM 2003).

Since the GMI, the industry has progressed: For example, operational safety and health have improved 
significantly, environmental management systems and impact assessments have become the norm for larger projects, community relations have been established and many mining companies report annually on their contributions to sustainable development.

\section{The Current Status}

We argue that, with the Rio declaration and the emergence of the three pillar model, as well as CSR, ("weak sustainability"), the sustainability aspect, expressed through environmental limits ("strong sustainability") got lost. In recent years, this "strong sustainability" position is becoming increasingly important on the societal agenda, given pressures such as climate change and biodiversity loss.

Could the mining industry again be falling behind societal expectations by setting on an outdated model? To test this argument, we conduct a literature review into the current state of the global environment, how this relates to sustainability considerations in academia and leading institutions and how it relates to the status in the mining industry and to other industries. With regards to environment, we focused on three key issues relevant to mining: climate change, water and biodiversity.

\section{State of the Environment}

The "great acceleration" has, as mentioned above, led to tremendous growth in the demand for mineral resources. More generally, it has let to tremendous global growth in GDP and population. On the upside, this meant big improvements to the living standards of a large proportion of humanity. On the downside, it meant a massive transformation of the environment, with such an impact that we are seeing the beginning of a new geological age, the Anthropocene (Steffen et al 2007).

The UN Environmental Programme (UNEP), with its mandate of "keeping the global environment under review" states the situation in its latest Global Environmental Outlook (GEO 5) as follows:

"The currently observed changes to the Earth System are unprecedented in human history. Efforts to slow the rate or extent of change - including enhanced resource efficiency and mitigation measures - have resulted in moderate successes but have not succeeded in reversing adverse environmental changes. Neither the scope of these nor their speed has abated in the past five years. As human pressures on the Earth System accelerate, several critical global, regional and local thresholds are close or have been exceeded. Once these have been passed, abrupt and possibly irreversible changes to the life-support functions of the planet are likely to occur, with significant adverse implications for human well-being. " (UNEP 2012)

\section{State in Academia and Leading Institutions}

Ecological Economics is an area of academic research relevant in the context of this paper. Influenced by the "The Limits to Growth" (Donella 1972) and contrary to neo- classical economics, ecological economics sees the economy as a subsystem of the environment, the "Earth system", which is materially a (more or less) closed system, only open to solar energy. In this view, economic growth "encroaches on other parts of the finite and non-growing whole, exacting a sacrifice of something - an opportunity cost" (Daly 2011), which makes it possible that at one stage economic growth becomes uneconomic, as the opportunity cost outweighs the growth. The argument now is that we have already reached this state (i.e. "a full world economy") and that "the welfare from economic services increases while the welfare from ecological services diminishes" (ibid.). To consider this in economics, ecological economists suggest, in addition to the traditional man-made capitals, to also include natural capital, which is " $a$ stock that yields a flow of natural services and tangible natural resources" (ibid.). Daly suggests that this also requires a paradigm shift from the traditional growth based economics view towards a "steady state economy at optimal scale" (ibid.). In recent years, the consideration of natural capital has made progress, with the organizations mentioned below playing a role but also through the Natural Capital Coalition, a global collaboration to harmonize approaches.

In 2009, a group of Earth system scientists, led by Will Steffen and Johan Rockström, published a concept called the Planetary Boundaries (Rockström et al 2009, Steffen et al 2015). Figure 2 below illustrates the framework.

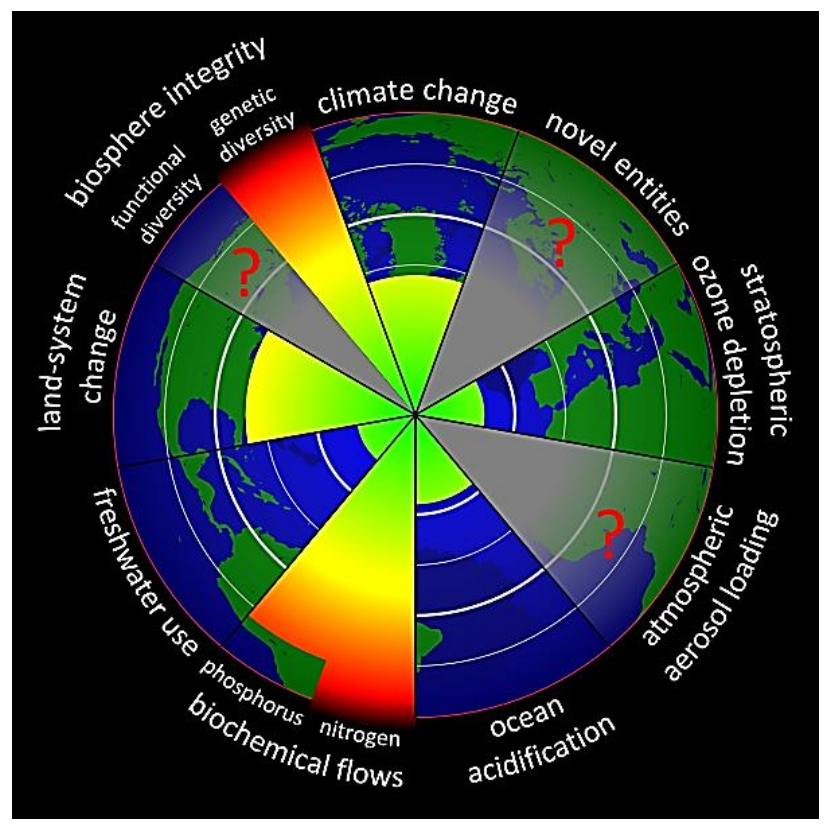

Figure 2. The Planetary Boundaries, acc.to Steffen et al 2015.

The framework "defines a safe operating space for humanity based on the intrinsic biophysical processes that regulate the stability of the Earth System" as a precondition for sustainable development. Crossing these boundaries brings the risk of "irreversible and abrupt environmental change", making our planet less habitable for humans.

Another science based framework for sustainability is The Natural Step. It was first described by Swedish scientist 
Karl-Henrik Robert in the late 1980s and has since developed into a non-profit NGO, which is promoting and advancing the framework, including consultation for business on how to use the framework in companies. It is based on four principles of how society should relate to nature and within itself (The Natural Step 2017).

To mobilize the global scientific knowledge on the challenges of sustainable development, UN SecretaryGeneral Ban Ki Moon in 2012 launched the Sustainable Development Solutions Network (SDSN). The SDSN supports Rio+20, but with a twist: It talks of environmental sustainability:

"The SDSN fully supports the Rio+20 vision of sustainable development as a holistic concept addressing four dimensions of society: economic development (including the end of extreme poverty), social inclusion, environmental sustainability, and good governance including peace and security. Societies aim to achieve all four dimensions. Failures in one area, such as environmental sustainability or gender equality, can undermine progress in others, such as the eradication of poverty." (SDSN 2014, p.ix)

In its "priority challenges of sustainable development" it also makes reference to the planetary boundaries. (ibid.)

The examples change the description of sustainable development to a model as shown in Figure 3 below. The concepts support a "strong sustainability" position.

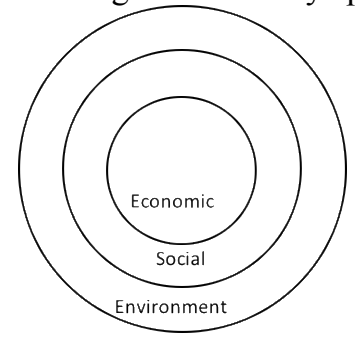

Figure 3. Nested circles model of sustainable development, based on environmental (and social) sustainability.

How far have the above examples been taken on?

The UN's webpage (UN 2017) defines sustainable development as "development that promotes prosperity and economic opportunity, greater social well-being, and protection of the environment". It states "the need to complete the job of eradicating poverty", as the key driver for the 2030 Agenda for Sustainable Development or SDGs, as they are known. The SDGs, adopted in 2015, are a set of 17 goals and 169 targets and are to "transform our world" and set "the 2030 agenda for sustainable development". Other than the MDGs, the SDGs are global goals for all countries and are broader, containing social (e.g. "no poverty" or "zero hunger"), economic (e.g. "decent work and economic growth") and environmental goals (e.g. "climate action or "life below water") and a governance related goal "partnerships for the goals". Whilst the SDGs align with the UN processes on climate change and biodiversity (which include absolute environmental targets), we argue that they are based on the three pillar model and support a "weak sustainability" position.
The World Bank Group (WBG) integrates "the principles of sustainable development into its work with clients across all sectors and regions:

"Ending extreme poverty within a generation and promoting shared prosperity must be achieved in such a way as to be sustainable over time and across generations. This requires promoting environmental, social, and fiscal sustainability. We need to secure the long-term future of our planet and its resources so future generations do not find themselves in a wasteland. We also must aim for sustained social inclusion and limit the size of economic debt inherited by future generations." (WBG 2017)

WBG's webpage is contradictious on what sustainable development really means to them. Whilst it mentions sustainability in its principles shown above, has an absolute position on climate change and supports countries in developing natural capital accounting practices (signs of a "strong sustainability" position) it is also focused on sustainable ("inclusive green") growth (a sign of a "weak sustainability" position).

The European Union (EU) considers itself a driver when it comes to advancing the sustainable development agenda, hence we choose the EU as the government example to look into. The Treaty of the European Union sets out the EU's vision for SD. It has since been integrated into EU policies and strategies, e.g. the EU 2020 Strategy. Looking into the future, the EU makes reference to the SDGs and its commitment "to be a frontrunner in implementing the 2030 Agenda and SDGs" (EC 2017). The EUs position can be considered one of "weak sustainability".

Two influential industry led organizations are also included in the analysis. The WBCSD is a "global organization of over 200 leading businesses working together to accelerate the transition to a sustainable world". In 2010, it published its "Vision 2050" (WBCSD 2010), which sets out a vision for the pathway to a sustainable world, with "a global population of some 9 billion people living well, within the resource limits of the planet by 2050." It has since published its "Action 2020" (WBCSD 2014), which is a first action plan on route to achieving the "Vision 2050". Current work includes "Redefining value" frameworks for natural (via the Natural Capital Coalition) and social capital accounting. The WBCSD's position is one of "strong sustainability".

The World Economic Forum (WEF) is an international institution committed to "improving the state of the world" by engaging business, political, academic and other leaders of society to shape global, regional and industry agendas. It recognizes the importance of sustainability in the context of its mission and runs a number of what it calls "The future of" initiatives including on "environment and natural resource security" and "economic growth and social inclusion", which are all based on a growth based neo-classical economic view. (WEF 2017) The WEF also published a report "Mining \& Metals in a Sustainable World 2050" (WEF 2015). Whilst it makes references to WBCSD and The Natural Step, it then continues with a "more sustainable 
world". Overall, the WEF can be considered a "weak sustainability" position.

\section{State in Mining}

In 2012, 10 years after the MMSD, the IIED did a review of the progress the industry has made against, recognizing a number of achievements (the ICMM being one of them), ongoing challenges (such as government capacity building or community development) and new issues (including the "wait and see" approach the industry has broadly taken on climate change).

"In short, the past 10 years have seen a valuable increase in the number of standards and best practice guidance, helping stakeholders to understand what sustainable development means. But despite good intentions at the strategy level and examples of good practice, the complexity of situations at the mine site means implementation across the sector is highly variable." (Buxton 2012)

In the context of this paper, the ICMM, already discussed above, supports a "weak sustainability" position.

Following the above literature review, a qualitative analysis of the companies listed in Table 1, using information available on their webpages (reference available by request), is conducted against the following criteria.

Table 1. Mining \& metals companies selected.

\begin{tabular}{ll}
\hline \multicolumn{1}{c}{ Name } & \multicolumn{1}{c}{ Reason for selection } \\
\hline Rio Tinto & Diversified, ICMM, WEF, DJSI \\
\hline BHP Billiton & Diversified, ICMM \\
\hline Anglo American & Diversified, ICMM, DJSI \\
\hline Glencore & Diversified, ICMM, WEF \\
\hline Areva & Uranium, ICMM \\
\hline ArcelorMittal & Iron and steel, WEF, WBCSD \\
\hline Vale & Diversified, WBCSD \\
\hline Newmont & Gold, ICMM, WEF, DJSI (mining leader) \\
\hline Barrick Gold & Gold, ICMM, DJSI \\
\hline Voestalpine & Steel, considered innovation leader, Austria \\
\hline MMG & Chinese owned, ICMM \\
\hline Alrosa & Diamonds, Russia \\
\hline Vedanta & India, ICMM, WBCSD, WEF \\
\hline Teck Resources & Canada, ICMM, WEF, DJSI \\
\hline
\end{tabular}

- What definition does the company use and what is the context (absolute sustainability or relative improvement): Sustainability, SD, CSR

- Does it consider any of the following:

- Ecological economics or natural capital

- Planetary Boundaries

- WBCSD's Vision 2050

- The Natural Step

- SDGs

- Does the company have absolute (i.e. leading to real reductions) or relative, efficiency based (which could still lead to absolute increases) targets for climate change, water and biodiversity?
Based on these criteria, each company's position is rated either as "strong sustainability" or "weak sustainability". Table 2 shows the results.

None of the mining companies currently support a "strong sustainability" position. Teck Resources' position can be considered as the most advanced in the context of this paper, as it is the only company with short and long term (2030), absolute goals, with biodiversity and water based on sustainability considerations (which their climate change goal, whilst absolute, isn't). A minority of the companies have absolute climate change targets with many, whilst considering climate change a threat, still having none at all. Only Vedanta is establishing a climate change target based on the Paris agreement, stating that it intends to match the INDCs in the countries it operates. Indeed, whilst many companies report on their performance and some mention overarching commitments to improvement, they still don't report on specific improvement goals. The companies do not mention their membership commitments other than ICMM's 10 principles (which ICMM obligates them to do) and Newmont mentioning their commitment to WEF's Responsible Mineral Development Initiative (RMDI); e.g. neither Vale nor ArcelorMittal as WBCSD members mention Vision 2050. The SDGs are taken seriously by the companies with a majority reporting on their support.

\section{State in Other Industries}

Subsequently, the mining companies are compared with companies in other industries listed in Table 2 below. These companies were chosen because they are the leaders of their respective sector in the current Dow Jones Sustainability Index (DJSI) (RobecoSam 2016) and the sector has some relation to mining, e.g. as a customer, supplier or financer.

Table 2. Companies used as peer group.

\begin{tabular}{ll}
\hline Name & Industry Group \\
\hline BMW & Automobiles \& Components \\
\hline Koninklijke Philips & Capital Goods \\
\hline LG Electronics & Consumer Durables \& Apparel \\
\hline UBS Group & Diversified Financials \\
\hline Thai Oil & Energy \\
\hline Unilever & Household \& Personal Products \\
\hline Swiss Re & Insurance \\
\hline Koninklijke DSM & Materials ${ }^{1}$ \\
\hline Hewlett Packard & Technology Hardware \& Equipment \\
\hline PostNL & Transportation \\
\hline Iberdrola & Utilities \\
\hline Stockland & Real Estate \\
\hline 1 Mining is part of the materials group, with DSM being the overall leader. \\
Newmont is the leader of the mining sub-group.
\end{tabular}

The criteria used are the same as described in section 5, although some of these companies do not consider all three environmental issues as material to their business.

Philips stands out, as they consider "reducing environmental impact and maintain the resources of our planet - enabling a sustainable planet" (Philips 2017) and as such is the only company referring to a "strong sustainability" position (which has not yet translated into all 
its goals, hence the W/S rating). Given the diversity of this group, not all consider water or biodiversity as material, however where biodiversity is considered the commitments are mostly not as strong (only Stockland supports "net positive contribution for new developments") as the mining companies'. All except Thai Oil and Stockland report on the
SDGs and half report some sort of involvement with natural capital initiatives or monetization of environmental issues. On climate change, all but Thai Oil have established targets, with many companies supporting absolute targets for their operations and relative targets for their products.

Table 3. Results of mining company assessment.

\begin{tabular}{|c|c|c|c|c|c|c|c|c|c|c|c|c|c|c|}
\hline & $\begin{array}{c}\text { Rio } \\
\text { Tinto }\end{array}$ & $\begin{array}{c}\text { BHP } \\
\text { Billiton }\end{array}$ & $\begin{array}{c}\text { Anglo } \\
\text { American }\end{array}$ & $\begin{array}{l}\text { Glen } \\
\text { core }\end{array}$ & Areva & $\begin{array}{c}\text { Arcelor } \\
\text { Mittal }\end{array}$ & Vale & $\begin{array}{l}\text { New } \\
\text { mont }\end{array}$ & $\begin{array}{c}\text { Barrick } \\
\text { Gold }\end{array}$ & $\begin{array}{l}\text { Voest } \\
\text { alpine }\end{array}$ & MMG & Alrosa & Vedanta & Teck \\
\hline Definition & $\mathrm{SD}$ & $\mathrm{S}$ & $\mathrm{S}$ & $\mathrm{S}$ & CSR & SD & $\mathrm{S} / \mathrm{SD}$ & $\mathrm{S}$ & CSR & CSR & $\mathrm{S} / \mathrm{SD}$ & $\mathrm{S}$ & $\mathrm{SD}$ & $\mathrm{S}$ \\
\hline Context & $\mathrm{R}$ & $\mathrm{R}$ & $\mathrm{R}$ & $\mathrm{R}$ & $\mathrm{R}$ & $\mathrm{R}$ & $\mathrm{R}$ & $\mathrm{R}$ & $\mathrm{R}$ & $\mathrm{R}$ & $\mathrm{R}$ & $\mathrm{R}$ & $\mathrm{R}$ & $\mathrm{R}$ \\
\hline $\begin{array}{l}\text { Ecological } \\
\text { Economics }\end{array}$ & $\mathrm{N}^{*}$ & $\mathrm{~N}$ & $\mathrm{~N}$ & $\mathrm{~N}$ & $\mathrm{~N}$ & $\mathrm{~N}^{*}$ & $\mathrm{~N}$ & $\mathrm{~N}$ & $\mathrm{~N}$ & $\mathrm{~N}$ & $\mathrm{~N}$ & $\mathrm{~N}$ & $\mathrm{~N}$ & $\mathrm{~N}^{* * *}$ \\
\hline $\begin{array}{l}\text { Planetary } \\
\text { Boundaries }\end{array}$ & $\mathrm{N}$ & & $\mathrm{N}$ & $\mathrm{N}$ & & & $N$ & & & & & 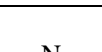 & $N$ & \\
\hline Vision 2050 & $\mathrm{~N}$ & $\mathrm{~N}$ & $\mathrm{~N}$ & $\mathrm{~N}$ & $\mathrm{~N}$ & $\mathrm{~N}$ & $\frac{\mathrm{N}}{\mathrm{N}}$ & $\mathrm{N}$ & $\frac{N}{N}$ & $\mathrm{~N}$ & $\frac{\mathrm{N}}{\mathrm{N}}$ & $\frac{N}{N}$ & $\frac{N}{N}$ & $\frac{\mathrm{N}}{\mathrm{N}}$ \\
\hline Natural Step & $\mathrm{N}$ & $\mathrm{N}$ & $\mathrm{N}$ & $\mathrm{N}$ & $\mathrm{N}$ & $\mathrm{N}$ & $\mathrm{N}$ & $\mathrm{N}$ & $\mathrm{N}$ & $\mathrm{N}$ & $\mathrm{N}$ & $\mathrm{N}$ & $\mathrm{N}$ & $\mathrm{N}$ \\
\hline SDGs & $\mathrm{Y}$ & $\mathrm{Y}$ & $\mathrm{Y}$ & $\mathrm{Y}$ & $\mathrm{N}$ & $\mathrm{Y}$ & $\mathrm{Y}$ & $\mathrm{Y}$ & $\mathrm{N}$ & $\mathrm{N}$ & $\mathrm{N}$ & $\mathrm{N}$ & $\mathrm{Y}$ & $\mathrm{Y}$ \\
\hline Climate Change & $\mathrm{R}$ & $\mathrm{A}$ & $\mathrm{R}$ & $\mathrm{N}$ & $\mathrm{A}$ & $\mathrm{R}$ & $\mathrm{R}$ & $\mathrm{N}$ & $\mathrm{N}$ & $\mathrm{N}$ & $\mathrm{N}$ & $\mathrm{N}$ & $\mathrm{A} / \mathrm{R}$ & $\mathrm{A}$ \\
\hline Water & $\mathrm{A} / \mathrm{R}$ & $\mathrm{A} / \mathrm{R}$ & $\mathrm{R}$ & $\mathrm{N}^{* *}$ & $\mathrm{R}$ & $\mathrm{N}$ & $\mathrm{N}$ & $\mathrm{N}^{* *}$ & $\mathrm{~N}^{* * *}$ & $\mathrm{~N}$ & $\mathrm{~A} / \mathrm{R}$ & $\mathrm{N}$ & $\mathrm{R}$ & $\mathrm{A}$ \\
\hline Land use & & & & & & & & & $\mathrm{R}$ & & $\mathrm{R}$ & $\mathrm{N}$ & & \\
\hline Biodiversity & $\mathrm{A} / \mathrm{R}$ & $\mathrm{A} / \mathrm{R}$ & $\mathrm{A} / \mathrm{R}$ & $\mathrm{A} / \mathrm{R}$ & $\mathrm{R}$ & $\mathrm{N}$ & $\mathrm{A} / \mathrm{R}$ & $\mathrm{A}$ & $\mathrm{R}$ & $\mathrm{R}$ & $\mathrm{R}$ & $\mathrm{N}$ & $\mathrm{A}$ & $\mathrm{A}$ \\
\hline Position & $\mathrm{W}$ & $\mathrm{W}$ & $\mathrm{W}$ & $\mathrm{W}$ & $\mathrm{W}$ & $\mathrm{W}$ & $\mathrm{W}$ & $\mathrm{W}$ & $\mathrm{W}$ & $\mathrm{W}$ & $\mathrm{W}$ & $\mathrm{W}$ & $\mathrm{W}$ & $\mathrm{W}$ \\
\hline $\begin{array}{l}\mathrm{R} \text { - relative } \\
* \text { Some natural } \\
* * \text { in developm } \\
* * * \text { mentions } 6\end{array}$ & $\begin{array}{l}\mathrm{A}-\mathrm{ab} \\
\mathrm{nd} / \text { or } \mathrm{s} \\
\mathrm{nt}\end{array}$ & $\begin{array}{l}\text { olute } \\
\text { ocial val }\end{array}$ & $\begin{array}{l}\text { Y- Yes } \\
\text { ation consi }\end{array}$ & $\begin{array}{r}\mathrm{N}-\mathrm{N} \\
\text { deratio }\end{array}$ & $\begin{array}{l}\text { eviden } \\
\text { s are me }\end{array}$ & $\begin{array}{l}\text { ce } \\
\text { entioned }\end{array}$ & $\mathrm{N}-\mathrm{we}$ & s susta & ability $\mathrm{p}$ & sition & & & & \\
\hline
\end{tabular}

Table 4. Results of the peer group assessment.

\begin{tabular}{|c|c|c|c|c|c|c|c|c|c|c|c|c|}
\hline & BMW & Philips & LG & UBS & $\begin{array}{l}\text { Thai } \\
\text { Oil }\end{array}$ & Unilever & Swiss Re & DSM & $\begin{array}{l}\text { Hewlett } \\
\text { Packard }\end{array}$ & Post NL & Iberdrola & Stockland \\
\hline Definition & $\mathrm{S}$ & $\mathrm{S}$ & $\mathrm{CSR} / \mathrm{S}$ & $\mathrm{S}$ & $\mathrm{CSR} / \mathrm{S}$ & $\mathrm{S}$ & $\mathrm{CR} / \mathrm{S}$ & $\mathrm{S}$ & $\mathrm{S}$ & $\mathrm{CR}$ & $\mathrm{S}$ & $\mathrm{S}$ \\
\hline Context & $\mathrm{R}$ & $\mathrm{R} / \mathrm{A}$ & $\mathrm{R}$ & $\mathrm{R}$ & $\mathrm{R}$ & $\mathrm{R}$ & $\mathrm{R}$ & $\mathrm{R}$ & $\mathrm{R}$ & $\mathrm{R}$ & $\mathrm{R}$ & $\mathrm{R}$ \\
\hline $\begin{array}{l}\text { Ecological } \\
\text { Economics }\end{array}$ & $\mathrm{N}$ & $\mathrm{N}^{*}$ & $\mathrm{~N}^{* *}$ & $\mathrm{~N}^{*}$ & $\mathrm{~N}$ & $\mathrm{~N}^{*}$ & $\mathrm{~N}$ & $\mathrm{~N}^{*}$ & $\mathrm{~N}$ & $\mathrm{~N}$ & $\mathrm{~N}^{*}$ & $\mathrm{~N}$ \\
\hline $\begin{array}{l}\text { Planetary } \\
\text { Boundaries }\end{array}$ & $\mathrm{N}$ & $\mathrm{Y}$ & $\mathrm{N}$ & $\mathrm{N}$ & $\mathrm{N}$ & $\mathrm{N}$ & $\mathrm{N}$ & $\mathrm{N}$ & $\mathrm{N}$ & $\mathrm{N}$ & $\mathrm{N}$ & $\mathrm{N}$ \\
\hline Vision 2050 & $\mathrm{Y}$ & $\mathrm{Y}$ & $\mathrm{N}$ & $\mathrm{N}$ & $\mathrm{N}$ & $\mathrm{N}$ & $\mathrm{N}$ & $\mathrm{N}$ & $\mathrm{N}$ & $\mathrm{N}$ & & $\mathrm{N}$ \\
\hline Natural Step & $\mathrm{N}$ & $\mathrm{N}$ & $\mathrm{N}$ & $\mathrm{N}$ & $\mathrm{N}$ & $\mathrm{N}$ & $\mathrm{N}$ & $\mathrm{N}$ & $\mathrm{N}$ & $\mathrm{N}$ & & $\mathrm{N}$ \\
\hline SDGs & $\mathrm{Y}$ & $\mathrm{Y}$ & $\mathrm{Y}$ & $\mathrm{Y}$ & $\mathrm{N}$ & $\mathrm{Y}$ & $\mathrm{Y}$ & $\mathrm{Y}$ & $\mathrm{Y}$ & $\mathrm{Y}$ & $\mathrm{Y}$ & $\mathrm{N}$ \\
\hline Climate Change & $\mathrm{R} / \mathrm{A}$ & A & A & $\mathrm{R}$ & $\mathrm{N}$ & $\mathrm{R} / \mathrm{A}$ & $\mathrm{R}$ & $\mathrm{R}$ & $\mathrm{R} / \mathrm{A}$ & $\mathrm{R}$ & $\mathrm{R} / \mathrm{A}$ & $\mathrm{R}$ \\
\hline Water & $\mathrm{R}$ & $\mathrm{A}$ & $\mathrm{R}$ & & $\mathrm{R}$ & $\mathrm{R} / \mathrm{A}$ & $\mathrm{R}$ & $\mathrm{N} * * *$ & $\mathrm{R}$ & & $\mathrm{R}$ & $\mathrm{R}$ \\
\hline Land use & & & & $\mathrm{R}$ & & $\mathrm{R}$ & & & & & & \\
\hline Biodiversity & & $\mathrm{R}$ & & $\mathrm{R}$ & $\mathrm{R}$ & $\mathrm{R}$ & & $\mathrm{R} / \mathrm{A}$ & & & $\mathrm{R}$ & A \\
\hline Position & $\mathrm{W}$ & $\mathrm{W} / \mathrm{S}$ & $\mathrm{W}$ & $\mathrm{W}$ & $\mathrm{W}$ & $\mathrm{W}$ & $\mathrm{W}$ & $\mathrm{W}$ & $\mathrm{W}$ & $\mathrm{W}$ & $\mathrm{W}$ & $\mathrm{W}$ \\
\hline $\begin{array}{l}\mathrm{R} \text { - relative } \\
* \text { Natural and/o } \\
* * \text { Monetarizat } \\
* * * \text { currently a }\end{array}$ & $\begin{array}{l}\text { ther ca } \\
\text { used } \mathrm{i} \\
\text { ssing v }\end{array}$ & $\begin{array}{l}\text { A - absc } \\
\text { pital con } \\
\text { n Korear } \\
\text { vater risk }\end{array}$ & $\begin{array}{l}\text { lute } \\
\text { sidered } \\
\text { operati }\end{array}$ & & $\overline{Y-Y e s}$ & & $\bar{N}-$ No ev & lence & & & & \\
\hline
\end{tabular}

\section{Conclusions}

Whilst we found evidence for concepts supporting a "strong sustainability" position in academia and the WBCSD, they have not yet become mainstream in the leading institutions considered in this analysis, i.e. the UN. Their SDGs can be considered the current status of societal expectations; with the majority of the companies in our analysis expressing support.
The mining industry is comparable to the results of the peer group. The peer group scores higher on climate change and natural capital valuation, but mining is more advanced in its approach towards biodiversity and water.

The analysis also showed that the use of term (S, SD, CSR, CR) doesn't say anything (in fact, many companies use more than one term), and definitions used are similar based on the three pillar model and a "weak sustainability" 
position. Only Philips makes reference to a "sustainable planet" and hence a "strong sustainability" position.

We come to the conclusion that the mining industry, whilst in a "weak sustainability" position and behind the peer group on climate change and natural capital considerations, is aligned with current societal expectations and hence there is no need for a GMI 2.0 at this stage.

\section{References}

Bowen, H., 1954. Social responsibilities of the businessman, American Catholic Sociological Review, 15(1): 266.

Buxton, A., 2012. MMSD+10: Reflecting on a decade, IIED Discussion Paper. International Institute for Environment and Development, London.

Carroll, A., 2008. A history of corporate social responsibility: concepts and practices, Oxford University Press, Oxford. https://www.researchgate.net/publication/282746355_A _History_of_Corporate_Social_Responsibility_Concept s_and_Practices.

Daly, H. and J. Farley, 2011. Ecological economics, principles and applications, 2nd Edition, Island Press, Washington, DC, America.

Donella, H., D. Meadows, L. Meadows, J. Randers and W. Behrens III, 1972. The limits to growth, Universe Books.

EC (European Commission), 2017. Sustainable development.

$\mathrm{http}: / /$ ec.europa.eu/environment/sustainabledevelopment/index_en.htm.

ICMM (International Council on Mining \& Metals), 2003. ICMM 10 principles.

http://www.icmm.com/en-gb/about-us/membercommitments/icmm-10-principles.

IIED (International Institute for Environment and Development: Breaking New Ground), 2002. Mining, Minerals and Sustainable Development. http://pubs.iied.org/search/?a=MMSD.

Moser, P, 2016. Raw materials as re-industrialization opportunities, Presentation at REinEU conference, Bratislava.

Philips, 2017. Healthy people, sustainable planet. http://www.philips.com/a-w/about/sustainability/ourapproach/ambition-2020.html.

RobecoSam, 2016. Industry Group Leaders 2016. http://www.robecosam.com/en/sustainabilityinsights/about-sustainability/corporate-sustainabilityassessment/industry-group-leaders.jsp.

Rockström, J., W. Steffen, K. Noone, A. Persson, F. S. Chapin III, E. Lambin, T.M. Lenton, M. Scheffer, C. Folke, H.J. Schellnhuber, C.A. de Wit, T. Hughes, et al, 2009. Planetary boundaries: Exploring the safe operating space for humanity. Ecology \& Society, 14(2): 292.
Steffen, W., P.J. Crutzen and J.R. McNeill, 2007. The anthropocene: are humans now overwhelming the great forces of nature. Ambio, 36(8): 614.

Steffen, W., K. Richardson, J. Rockstrom, S.E. Cornell, I. Fetzer, E.M. Bennett, R. Biggs, S.R. Carpenter, W. De Vries, C.A. De Wit, C. Folke, D. Gerten, J. Heinke, G.M. Mace, L.M. Persson, V. Ramanathan, B. Reyers and S. Sorlin, 2015. Planetary boundaries: Guiding human development on a changing planet. Science, 347: 6223.

SDSN (Sustainable Development Solutions Network), 2014. An action agenda for sustainable development, http://unsdsn.org/wp-content/uploads/2013/06/140505An-Action-Agenda-for-Sustainable-Development.pdf.

The Natural Step webpage, 2017. The Natural Step. http://www.thenaturalstep.org/our-approach/.

Turner, R., 1993. Sustainable environmental economics and management: principles and practice, London, Belhaven Press.

UN (United Nations webpage), 2017. Promote sustainable development.

http://www.un.org/en/sections/what-we-do/promotesustainable-development/index.html.

UNCED (United Nations Conference on Environment and Development), 1992. The Rio Declaration on Environment and Development.

UNEP (United Nations Environment Programme), 2012. GEO (Global Environment Outlook) 5. http://www.unep.org/geo/sites/unep.org.geo/files/docu ments/geo5_spm_english.pdf

WBG (World Bank Group), 2017. Sustainable development. http://www.worldbank.org/en/topic/sustainabledevelop ment.

WEF (World Economic Forum), 2015. Mining \& metals in a sustainable world 2050, http://www3.weforum.org/docs/WEF_MM_Sustainable _World_2050_report_2015.pdf.

WEF (World Economic Forum), 2017. World Economic Forum Sustainability Policy, http://www3.weforum.org/docs/WEF_Sustainability_P olicy_EN.pdf.

WBCSD (World Business Council for Sustainable Development), 2010. Vision 2050, the new agenda for business, http://www.wbcsd.org/Overview/Aboutus/Vision2050/Resources/Vision-2050-The-newagenda-for-business.

WBCSD (World Business Council for Sustainable Development), 2014. Action 2020. http://www.wbcsd.org/Overview/Aboutus/Action2020/Resources/Action2020-Overview.

WCED (World Commission on Environment and Development), 1987. Our common future. http://www.un-documents.net/ocf-02.htm\#I. 